\title{
Fermentation-derived Aroma Compounds in Varietal Young Wines from South Africa
}

\author{
L. Louw ${ }^{1,2}$, A.G.J. Tredoux ${ }^{1}$, P. Van Rensburg ${ }^{1,2}$, M. Kidd ${ }^{3}$, T. Naes ${ }^{4}$ and H.H. Nieuwoudt ${ }^{1 *}$
}

(1) Institute for Wine Biotechnology, Department of Viticulture and Oenology, Stellenbosch University, Private Bag X1, 7602, Matieland, South Africa

(2) Distell Ltd., P.O. Box 184, Stellenbosch 7602, South Africa

(3) Centre for Statistical Consultation, Stellenbosch University, Private Bag X1, Matieland 7602, South Africa

(4) Nofima Mat, Oslovegen 1, 1430 Ås, Norway

Submitted for publication: May 2010

Accepted for publication: September 2010

Key words: South African young wines, GC-FID, aroma compounds, odour activity, discriminant analysis

\begin{abstract}
The volatile composition of 925 single cultivar young Sauvignon blanc, Chardonnay, Pinotage, Merlot, Shiraz and Cabernet Sauvignon wines of vintages 2005 to 2007, was determined using gas chromatography - flame ionisation detection. Compositional data were compared to published data on young wines from South Africa and other countries. South African young wines analysed in this study had a largely similar volatile composition to that reported in the literature. Significant between-vintage and between-cultivar differences were observed in the volatile composition of the wines investigated in this study. The concentration ranges of four compounds in red wines, hexanol, propanol, diethyl succinate and ethyl lactate, and four compounds in white wines, 2-phenylethanol, hexanoic acid, isoamyl acetate and propanol, were not influenced by vintage effects. This finding was interpreted as the first indication that typical concentration ranges for some aroma compounds can be established for South African young cultivar wines. A trend was observed in the white wines that the alcohols and their respective acetate esters, as well as fatty acids and their ethyl esters, were responsible for the vintage-related effects. Differences in volatile composition between Chardonnay and Sauvignon blanc wines could also largely be explained on the same basis. Classification models were established to discriminate between individual red wine cultivars and between the two white wine cultivars and correct classification rates of respectively, $79 \%$ and $85 \%$ were achieved.
\end{abstract}

\section{INTRODUCTION}

Over the years, many researchers have strived to better understand wine composition. Studies, past and ongoing, have focussed on, amongst other topics, the identification of wine compounds (Noble et al., 1980; Campo et al., 2006), methods of quantification (Ferreira et al., 2000; 2001) and the role of individual compounds and compound classes in wine flavour and quality (Etievant, 1991; Guth 1997; Ferreira et al., 2000 and 2001; Barbe et al., 2008). Many studies also investigated the contribution of various wine compounds to the differentiation between wines of different cultivars (Ferreira et al., 2000; Lee and Noble, 2003; Tredoux et al., 2008; Weldegergis and Crouch, 2008), geographic origin (Marais et al., 1981 a and b; Calleja and Falque, 2005) and the variation of wine composition over vintages (Ferreira et al., 2000; Zhang et al., 2007).

The volatile composition of wine is directly responsible for the aroma, and therefore the quality of wine. Some grape-derived compounds such as methoxypyrazines, contribute significantly to wine aroma (Lacey et al., 1991; Sefton et al., 1993), while fermentation-derived volatiles such as alcohols, esters and fatty acids have also been shown to play an important role (Schreier, 1979). The most abundant alcohols in wine, apart from ethanol, are 1-propanol, isobutanol, isoamyl alcohol and 2-phenylethanol
(Rapp and Mandery, 1996). These higher alcohols have a pungent smell at high concentrations, but add to the complexity of wine when present at less than $0.30 \mathrm{~g} / \mathrm{L}$. Esters of saturated carboxylic acids, such as ethyl hexanoate, and acetate esters of higher alcohols, such as isoamyl acetate, are generally associated with fruity, floral wine aromas (Aznar et al., 2001).

Aliphatic saturated fatty acids are the most common fatty acids found in wine and chain lengths of up to 14 carbon atoms have been reported (Schreier, 1979). Acetic, hexanoic, octanoic and decanoic acids are some of the most abundant fatty acids in wine. At high concentrations, these compounds are associated with rancid, cheesy and vinegar-like aromas, but they are usually present below their detection threshold in healthy wines (Schreier, 1979; Lambrechts and Pretorius, 2000). However, these volatile compounds can influence wine aroma even at levels below odour threshold.

Strong correlations have been found between grape variety and the concentrations of main groups of compounds derived from yeast amino acid metabolism, namely isoacids and ethyl esters of isoacids, as well as fusel alcohols and fusel alcohol acetates (Ferreira et al., 2000), and it was suggested that the amino acid profiles of grapes contribute significantly to the aromatic differences between cultivar wines. Several studies support the

Acknowledgements: The authors wish to acknowledge funding by Winetech, The National Research Foundation and the Harry Crossley Foundation. Hugh Jumat and Karolien Roux are thanked for their valuable contributions.

*email:hhn@sun.ac.za 
contribution of higher alcohols, esters and fatty acids to varietal differentiation (Danzer et al., 1999; Lopéz et al., 1999; Falqué et al., 2001; Camara et al., 2006). Differences in the higher alcohol, ester and fatty acid composition of wines from different wine producing areas have also been observed (Marais et al., 1981 a and b; Calleja and Falqué 2005).

The aim of this study was to gain perspective on the volatile composition of South African (SA) young wines, defined as single-cultivar wines that have not yet undergone ageing, in order to exclude variability due to oak maturation, blending and bottle ageing. Six wine cultivars, sourced from all major wine producing areas of South Africa were included in this study and in total 925 wines were analysed. The composition of wines from vintages 2005 to 2007 in terms of 26 abundant fermentation-derived volatile compounds was compared to published data of wines from other countries. Comparisons between the SA cultivars were made, in order to establish profiles for each cultivar. Possible vintage-related effects on the average concentration ranges of volatile compounds were investigated, to evaluate if typical concentration ranges for volatile compounds in each cultivar could be established. Finally, it was also attempted to develop classification models that could discriminate between the different red and white cultivars.

\section{MATERIALS AND METHODS}

\section{Wines}

A total of 925 single varietal bottled young wines that were entered in the annual SA Young Wine Shows (organised by the SA Wine Show Association) of 2005, 2006 and 2007, were analysed (Table 1). Sauvignon blanc, Chardonnay, Pinotage, Merlot, Cabernet Sauvignon and Shiraz wines from cellars from Stellenbosch, Paarl, Worcester, Robertson, Orange River, Olifants River, Elgin, Helderberg, Franschoek, Darling, Swartland, Tulbagh, Cape Point, Little Karoo and Durbanville were used. However, as SA wine producers are permitted by law to purchase grapes from other geographic regions for wine production, the location of the cellars was not deemed an accurate indication of the true geographic origin of the wine. Therefore, discrimination between wines from different geographic origins was not considered in this study. The wines were protected against oxidation and stored at $4^{\circ} \mathrm{C}$ in the dark until analysed.

\section{TABLE 1}

Number of wine samples in each cultivar for vintages 2005 to 2007.

\begin{tabular}{lcccc}
\hline Cultivar & $\mathbf{2 0 0 5}$ & $\mathbf{2 0 0 6}$ & $\mathbf{2 0 0 7}$ & Total \\
\hline Sauvignon blanc & 69 & 48 & 64 & 181 \\
Chardonnay & 43 & 42 & 40 & 125 \\
Pinotage & 47 & 43 & 39 & 129 \\
Shiraz & 58 & 62 & 47 & 167 \\
Cabernet Sauvignon & 69 & 37 & 55 & 161 \\
Merlot & 62 & 53 & 47 & 162 \\
Total & 348 & 285 & 292 & 925 \\
\hline
\end{tabular}

\section{Chemicals, standards and wine matrix simulant}

\section{Chemicals and standards}

Ethyl acetate and isoamyl acetate were purchased from Riedel de Haën (Seelze, Germany). Methanol, hexanol, acetic acid and 2-phenylethanol, diethyl ether, ethanol, tartaric acid, $\mathrm{NaOH}$ and $\mathrm{Na}_{2} \mathrm{SO}_{4}$ were purchased from Merck (Darmstadt, Germany). Ethyl butyrate, propanol, isobutanol, butanol, hexyl acetate, ethyl lactate, propionic acid, isobutyric acid, butyric acid, isovaleric acid, diethyl succinate, valeric acid, 2-phenylethyl acetate, 4-methyl2-pentanol (internal standard) and hexane were purchased from Fluka (Buchs, Switzerland). Hexanoic acid, octanoic acid, isoamyl alcohol, ethyl octanoate and ethyl decanoate were purchased from Aldrich (Steinheim, Germany). Decanoic acid and ethyl hexanoate were purchased from Sigma (St. Louis, USA). All the compounds used were of at least $98 \%$ purity.

\section{Wine matrix simulant composition}

A wine matrix simulant consisting of $12 \% \mathrm{v} / \mathrm{v}$ ethanol and $2.5 \mathrm{~g} / \mathrm{L}$ tartaric acid in de-ionised water from a MilliQ water purifying system (Millipore, Billeric, MA, USA), pH adjusted to 3.50 with $0.1 \mathrm{M} \mathrm{NaOH}$ was used for identification and calibration purposes. The pure standards and the internal standard, 4-methyl-2-pentanol, were also dissolved in this solution.

\section{Liquid-liquid extraction procedure and quantitation}

Five $\mathrm{mL}$ of wine with internal standard 4-methyl-2-pentanol added (100 $\mu \mathrm{L}$ of $0.50 \mathrm{mg} / \mathrm{L}$ solution in wine simulant) was extracted with one $\mathrm{mL}$ of diethyl ether by sonicating the ether/wine mixture for five minutes. The wine/ether mixture was then centrifuged at $3600 \mathrm{~g}$ for 3 minutes. The ether layer (supernatant) was removed and dried on $\mathrm{Na}_{2} \mathrm{SO}_{4}$.

\section{Gas chromatographic conditions}

For gas chromatography (GC) a DB-FFAP capillary column (Agilent, Little Falls, Wilmington, USA) with dimensions 60 m length $\times 0.32 \mathrm{~mm}$ i.d. $\times 0.5 \mu \mathrm{m}$ film thickness and a Hewlett Packard 6890 Plus GC instrument (Little Falls, USA) equipped with a split/splitless injector and an flame ionisation detector (FID) was used. The initial oven temperature was $33^{\circ} \mathrm{C}$, held for 17 minutes, after which the temperature was increased by $12^{\circ} \mathrm{C} /$ minute to $240^{\circ} \mathrm{C}$, and held for 5 minutes. Three $\mu \mathrm{L}$ of the diethyl ether extract was injected at $200^{\circ} \mathrm{C}$ in split mode. The split ratio was $15: 1$ and the split flow rate $49.5 \mathrm{~mL} /$ minute. The column flow rate was $3.3 \mathrm{~mL} /$ minute using hydrogen as carrier gas. The detector temperature was $250^{\circ} \mathrm{C}$. After each sample run, a post run of 5 minutes at oven temperature $240^{\circ} \mathrm{C}$, with a column flow of 6 $\mathrm{mL} /$ minute cleaned the column from high boiling contaminants. The GC-FID method described above, including the sample preparation procedure, has been validated (Louw, 2007) and applied in a previous study (Louw et al., 2009). The limits of detection (LOD) and quantification (LOQ) for the analytes are shown in Table 2 . The relative standard deviation (\%RSD) was below $10 \%$ for all compounds

\section{Statistics}

All statistical analyses were done in the Statistica 8 software package (Statsoft Inc., www.statsoft.com). 


\section{Univariate analysis}

Factorial analysis of variance (ANOVA) tests were performed on the wine volatile data to determine whether significant differences exist between vintages and cultivars and to evaluate the significance of vintage*cultivar interactions. Least significance difference (LSD) post-hoc tests were performed for further interpretation of the ANOVA results at $\alpha=5 \%$. Box plots were drawn to determine non-outlier concentration ranges, defined as the $95 \%$ confidence intervals. Odour activity values were calculated for each compound by dividing the average concentration by the

\section{TABLE 2}

Limit of detection (LOD) and limit of quantification (LOQ) for analysis of volatile compounds using GD-FID analysis .

\begin{tabular}{|c|c|c|}
\hline Compound & LOD $^{b}$ & $\mathbf{L O Q}^{\mathrm{c}}$ \\
\hline \multicolumn{3}{|l|}{ Alcohols } \\
\hline Methanol & 10.98 & 36.59 \\
\hline Propanol & 0.25 & 0.82 \\
\hline Butanol & 0.06 & 0.20 \\
\hline Isoamyl Alcohol & 0.02 & 0.06 \\
\hline Isobutanol & 0.05 & 0.16 \\
\hline Hexanol & 0.02 & 0.05 \\
\hline 2-Phenylethanol & 0.06 & 0.20 \\
\hline \multicolumn{3}{|l|}{ Esters } \\
\hline Ethyl Acetate & 0.10 & 0.35 \\
\hline Ethyl Butyrate & 0.02 & 0.06 \\
\hline Isoamyl Acetate & 0.01 & 0.05 \\
\hline Ethyl Hexanoate & 0.02 & 0.07 \\
\hline Hexyl Acetate & 0.02 & 0.07 \\
\hline Ethyl Lactate & 0.52 & 1.72 \\
\hline Ethyl Octanoate & 0.02 & 0.06 \\
\hline Ethyl Decanoate & 0.07 & 0.23 \\
\hline Diethyl Succinate & 0.03 & 0.09 \\
\hline 2-Phenylethyl Acetate & 0.01 & 0.04 \\
\hline \multicolumn{3}{|l|}{ Acids } \\
\hline Acetic Acid & 1.21 & 4.04 \\
\hline Propionic Acid & 0.22 & 0.73 \\
\hline Iso-Butyric Acid & 0.06 & 0.20 \\
\hline Butyric Acid & 0.02 & 0.07 \\
\hline Iso-Valeric Acid & 0.03 & 0.10 \\
\hline Valeric Acid & 0.03 & 0.10 \\
\hline Hexanoic Acid & 0.02 & 0.05 \\
\hline Octanoic Acid & 0.04 & 0.12 \\
\hline Decanoic Acid & 0.04 & 0.12 \\
\hline
\end{tabular}

${ }^{\mathrm{a}}$ Louw, 2007; bimit of detection; ' ${ }^{\mathrm{c}}$ Limit of quantification. compound's odour threshold levels, as reported in literature (Guth 1997). Compounds with odour activity values $\geq 1$ are considered odour active i.e. they contribute to aroma.

\section{Multivariate analysis}

A method for selecting subsets of variables using genetic algorithms was performed to identify the subsets of volatile compounds that best discriminated between cultivars. The fitness criteria used in the genetic algorithm was classification accuracy based on a 'hold out' test data set. A total of 21 subsets were identified and the best of these were used in a linear discriminant analysis (LDA) test (Otto, 1999) to determine how well wines could be classified into their respective cultivar groups based on the specific subset. Compounds that appeared in at least 16 of the 21 subsets were grouped into an additional subset of compounds, namely the "most used" subset. The "most used" subset was also used in a LDA test. All the LDA models were validated using an independent test set.

\section{RESULTS AND DISCUSSION}

\section{Fermentation-derived compounds in white wines}

The concentration levels of the volatile compounds in Chardonnay and Sauvignon blanc wines, along with their respective odour description, threshold and odour activity values, are listed in Table 3. To date, very few studies on the distribution of volatile compounds in SA young white wines have been undertaken and to the best of our knowledge this report is one of the first comprehensive studies of its nature. An earlier study on the SA Colombar and Chenin blanc (Marais et al., 1981 b) showed results comparable to the findings in the present study. However, for ethyl acetate $(39.30-48.30 \mathrm{mg} / \mathrm{L})$ and hexyl acetate $(0.09$ $0.19 \mathrm{mg} / \mathrm{L})$, lower amounts were reported by Marais et al. as well as higher levels of ethyl octanoate (1.35 - $1.55 \mathrm{mg} / \mathrm{L})$.

In comparison to white wine cultivars from other countries, SA and Californian Chardonnay wines compared well (Lee and Noble, 2003), although lower concentration ranges of ethyl acetate (n.d. - $7.90 \mathrm{mg} / \mathrm{L})$, propanol $(0.10-0.70 \mathrm{mg} / \mathrm{L})$ and acetic acid $(6.50$ $45.80 \mathrm{mg} / \mathrm{L})$, and a higher concentration range for octanoic acid $(10.20-50.60 \mathrm{mg} / \mathrm{L})$ were reported for the Californian wines. Another report on Californian Chardonnay wines (Arrhenius et al., 1996) reported ethyl lactate concentrations between 0.07 - $3.50 \mathrm{mg} / \mathrm{L}$ and 2-phenylethanol levels of between $0.70-4.80$ $\mathrm{mg} / \mathrm{L}$. These results are lower than the average levels found for SA Chardonnay wines analysed.

Results published by Cabrita et al. in 2007, although pertaining to different cultivars than investigated here, showed that Portuguese white wines had concentration ranges of fermentation-derived compounds comparable to that of SA white wines. The Portuguese wines had lower levels of ethyl acetate $(27-65 \mathrm{mg} / \mathrm{L})$, butanol (0.07 - $0.29 \mathrm{mg} / \mathrm{L})$, ethyl decanoate $(0.01-0.05 \mathrm{mg} / \mathrm{L})$, ethyl octanoate $(0.15-0.32 \mathrm{mg} / \mathrm{L})$, diethyl succinate (n.d. - 0.22 $\mathrm{mg} / \mathrm{L})$, butyric acid $(0.04-0.40 \mathrm{mg} / \mathrm{L})$ and isobutyric acid $(0.07$ - $0.15 \mathrm{mg} / \mathrm{L}$ ) than the SA wines (Table 3). In a recent study of Spanish white wines, concentration levels of volatile compounds were reported that compared fairly well to the SA white wines, although different cultivars were investigated (Gil et al., 2006). The Spanish wines had lower levels of hexyl acetate (trace levels) and higher levels of diethyl succinate $(2.97 \mathrm{mg} / \mathrm{L})$, butyric acid $(4.95 \mathrm{mg} / \mathrm{L})$ and ethyl octanoate $(5.22 \mathrm{mg} / \mathrm{L})$. 


\section{Differentiation between vintages}

The factorial ANOVA on Chardonnay and Sauvignon blanc data showed that the concentration levels of 20 of the 26 quantified volatile compounds changed significantly over vintages 2005 to 2007 (Table 4). The exception was 2-phenylethanol, acetic acid, ethyl hexanoate, hexanoic acid, isoamyl alcohol and propanol (Figure 1). The vintage*cultivar interaction was also insignificant for 2-phenylethanol, hexanoic acid, isoamyl alcohol and propanol. This suggests that the differences between the two cultivars in terms of these compounds are not affected by vintage and could therefore be characteristic of the cultivar. The finding that the levels at which these compounds occurred in the two cultivars remained constant over the three years is the first indication that typical concentration ranges can be established for some volatile compounds in South Africa cultivar wines. However, it is possible that changing environmental conditions and viticultural and oenological practices can affect future concentrations ranges observed. The analysis of future vintages will assist in critical evaluation of these preliminary findings.

Of the 26 different volatiles analysed, the following compounds were affected by vintage, but the vintage*cultivar interaction was non-significant: butanol, diethyl succinate, ethyl acetate, ethyl lactate, isobutanol, isobutyric acid, methanol, propionic acid and valeric acid (Table 4). This means that the changes that occurred over vintage were the same for Chardonnay and Sauvignon blanc. In contrast, the following compounds changed over vintage, although in different ways in Chardonnay and Sauvignon blanc: 2-phenyl acetate, butyric acid, decanoic acid, ethyl butyrate, ethyl decanoate, ethyl octanoate, hexanol, hexyl acetate, isoamyl acetate, isovaleric acid and octanoic acid (Table 4). Most compounds in this list can be grouped into pairs consisting of a fatty acid and its corresponding ethyl ester, or a higher alcohol and its corresponding acetate ester. Examples are butyric acid and ethyl butyrate, octanoic acid and ethyl octanoate, decanoic acid and ethyl decanoate, hexanol and hexyl acetate. Ethyl and acetate esters are formed via the esterification of ethanol and acetic acid (Etievant, 1991). There was no obvious trend in vintage related changes in the acids or alcohols and their corresponding esters. It is known that Chardonnay and Sauvignon blanc follow different ripening patterns (Conde et al., 2007) and climatic and environmental conditions in the vineyards will affect the chemical composition of the grapes (and possibly the precursors of the listed ester/acid and ester/alcohol pairs) differently. More studies are needed to investigate these observations.

\section{Differentiation between cultivars}

A comparison of the volatile composition of Sauvignon blanc and Chardonnay wines is shown in Table 3 . Ten of the 19 compounds that differed significantly between the two cultivars were present at levels above their respective odour thresholds and can therefore be considered odour active. The differentiation between Sauvignon blanc and Chardonnay wines in terms of these compounds are shown in Figure 2. Sauvignon blanc contained significantly more acetic acid, decanoic acid, ethyl decanoate, octanoic acid, ethyl octanoate, isoamyl alcohol, isoamyl acetate, hexanoic acid, hexanol, 2-phenylethanol, 2-phenyl ethyl acetate and isobutanol, than Chardonnay. The first 8 compounds in this list occurred above their respective odour active concentration levels (Table 3 ). The compounds that occurred at higher levels in Sauvignon blanc wines are chemically related. There are two cases of corresponding alcohols and esters and two sets of corresponding
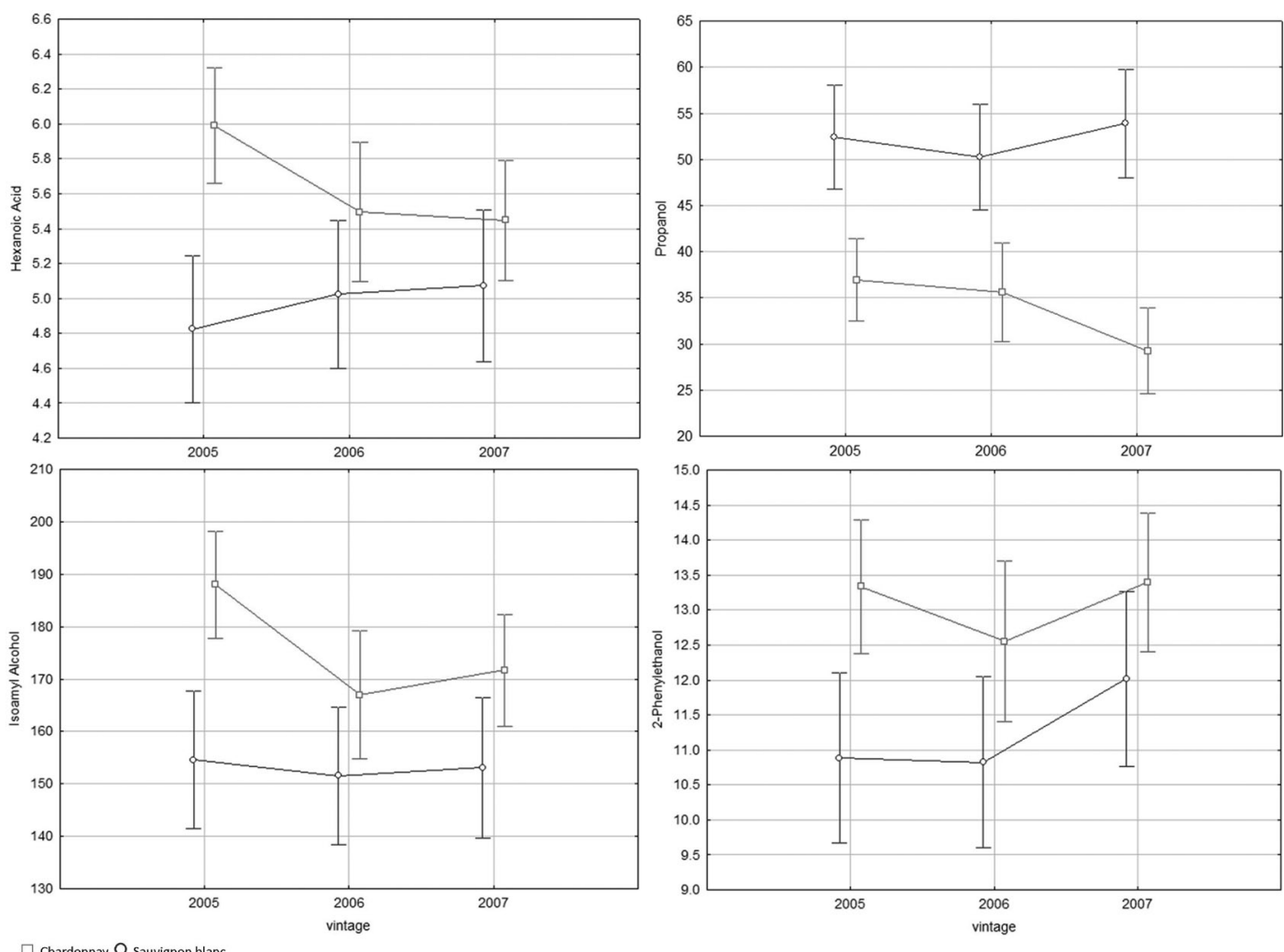

FIGURE 1

Aroma compounds that occurred at consistent levels in South African young white Chardonnay and Sauvignon blanc wines over the course of vintages 2005 to 2007. 
TABLE 3

Volatile composition of young SA white wines studied.

\begin{tabular}{|c|c|c|c|c|c|c|c|c|}
\hline & \multirow{2}{*}{ Odor description } & \multirow{2}{*}{$\begin{array}{l}\mathrm{OTH}^{1} \\
(\mathrm{mg} / \mathrm{L})\end{array}$} & \multicolumn{3}{|c|}{ Chardonnay $(\mathrm{n}=125)$} & \multicolumn{3}{|c|}{ Sauvignon blanc $(\mathrm{n}=181)$} \\
\hline & & & $\begin{array}{l}\text { Minimum -maximum } \\
\text { Mean } \pm \mathrm{SD}^{2}(\mathrm{mg} / \mathrm{L})\end{array}$ & & OAV ${ }^{3}$ & $\begin{array}{c}\text { Minimum-maximum } \\
\text { Mean } \pm \mathrm{SD}^{2}(\mathrm{mg} / \mathrm{L})\end{array}$ & & OAV \\
\hline \multicolumn{9}{|l|}{ Alcohols } \\
\hline Methanol & - & $\mathrm{n} / \mathrm{a}^{4}$ & $\begin{array}{l}25.14-482.00 \\
83.77 \pm 55.75\end{array}$ & $a^{5}$ & $\mathrm{n} / \mathrm{a}^{4}$ & $\begin{array}{l}16.02-180.47 \\
67.79 \pm 30.31\end{array}$ & $\mathrm{~b}$ & $\mathrm{n} / \mathrm{a}^{4}$ \\
\hline Propanol & Alcohol, ripe fruit & $306^{6}$ & $\begin{array}{l}12.36-149.27 \\
52.18 \pm 25.17\end{array}$ & a & 0.17 & $\begin{array}{l}10.34-82.65 \\
33.88 \pm 13.05\end{array}$ & $\mathrm{~b}$ & 0.11 \\
\hline Butanol & Fusel odour, medicinal & $150^{7}$ & $\begin{array}{l}0.20-2.13 \\
0.88 \pm 0.53\end{array}$ & a & 0.01 & $\begin{array}{l}0.20-2.54 \\
0.78 \pm 0.44\end{array}$ & $\mathrm{~b}$ & 0.01 \\
\hline Isoamyl Alcohol & Alcoholic, harsh & $40^{8}$ & $\begin{array}{l}86.35-394.93 \\
153.06 \pm 38.02\end{array}$ & $\mathrm{~b}$ & 5.10 & $\begin{array}{c}115.40-394.35 \\
176.65 \pm 46.79\end{array}$ & a & 5.89 \\
\hline Isobutanol & Fusel, alcohol & $30^{8}$ & $\begin{array}{l}2.27-45.03 \\
15.79 \pm 8.66\end{array}$ & $\mathrm{~b}$ & 0.39 & $\begin{array}{l}2.26-66.32 \\
18.58 \pm 8.95\end{array}$ & $\mathrm{a}$ & 0.46 \\
\hline Hexanol & Grassy & $8^{8}$ & $\begin{array}{l}0.05-2.73 \\
1.01 \pm 0.43\end{array}$ & $\mathrm{~b}$ & 0.13 & $\begin{array}{l}0.13-4.11 \\
1.25 \pm 0.58\end{array}$ & a & 0.16 \\
\hline 2-Phenylethanol & Roses & $14^{9}$ & $\begin{array}{l}5.26-35.00 \\
11.23 \pm 3.58\end{array}$ & $\mathrm{~b}$ & 0.80 & $\begin{array}{l}6.89-32.78 \\
13.15 \pm 4.30\end{array}$ & a & 0.94 \\
\hline \multicolumn{9}{|l|}{ Esters } \\
\hline Ethyl Acetate & Varnish, fruity, solvent & $12.26^{10}$ & $\begin{array}{l}6.24-185.78 \\
87.44 \pm 28.67\end{array}$ & a & 7.13 & $\begin{array}{c}30.22-233.58 \\
88.79 \pm 32.49\end{array}$ & $\mathrm{a}$ & 7.24 \\
\hline Ethyl Butyrate & Acidic, fruity, apple & $0.02^{8}$ & $\begin{array}{l}0.06-1.97 \\
0.52 \pm 0.36\end{array}$ & $\mathrm{a}$ & 25.77 & $\begin{array}{l}0.06-0.80 \\
0.28 \pm 0.14\end{array}$ & $\mathrm{~b}$ & 13.80 \\
\hline Isoamyl Acetate & Banana & $0.03^{8}$ & $\begin{array}{c}0.26-14.88 \\
4.85 \pm 2.52\end{array}$ & $\mathrm{~b}$ & 161.64 & $\begin{array}{l}1.09-18.45 \\
5.63 \pm 2.73\end{array}$ & a & 187.77 \\
\hline Ethyl Hexanoate & Green apple & $0.014^{9}$ & $\begin{array}{l}0.07-2.32 \\
0.95 \pm 0.55\end{array}$ & a & 68.05 & $\begin{array}{l}0.22-2.11 \\
0.90 \pm 0.44\end{array}$ & a & 64.24 \\
\hline Hexyl Acetate & Apple, cherry, pear, floral & $1.5^{7}$ & $\begin{array}{l}0.07-1.70 \\
0.51 \pm 0.51\end{array}$ & a & 0.34 & $\begin{array}{l}0.07-2.48 \\
0.56 \pm 0.63\end{array}$ & a & 0.37 \\
\hline Ethyl Lactate & Lactic, buttery, fruity & $154.6^{10}$ & $\begin{array}{c}0.92-80.24 \\
12.36 \pm 14.27\end{array}$ & a & 0.08 & $\begin{array}{l}1.56-29.52 \\
9.55 \pm 6.05\end{array}$ & $\mathrm{~b}$ & 0.06 \\
\hline Ethyl Octanoate & Sweet, soapy, fruity & $0.005^{9}$ & $\begin{array}{l}0.29-1.34 \\
0.60 \pm 0.21\end{array}$ & a & 119.62 & $\begin{array}{l}0.27-1.77 \\
0.71 \pm 0.28\end{array}$ & $\mathrm{~b}$ & 142.52 \\
\hline Ethyl Decanoate & Grape, pleasant, soapy & $0.2^{9}$ & $\begin{array}{l}0.23-0.61 \\
0.27 \pm 0.08\end{array}$ & $\mathrm{~b}$ & 1.36 & $\begin{array}{l}0.23-2.58 \\
0.53 \pm 0.56\end{array}$ & a & 2.64 \\
\hline Diethyl Succinate & Fruity, melon & $200^{7}$ & $\begin{array}{l}0.09-4.58 \\
0.86 \pm 0.84\end{array}$ & a & 0.00 & $\begin{array}{l}0.09-4.89 \\
0.45 \pm 0.54\end{array}$ & $\mathrm{~b}$ & 0.00 \\
\hline 2-Phenylethyl Acetate & Rose, honey, tobacco & $0.25^{8}$ & $\begin{array}{l}0.04-0.63 \\
0.16 \pm 0.12\end{array}$ & a & 0.64 & $\begin{array}{l}0.04-1.47 \\
0.25 \pm 0.20\end{array}$ & $\mathrm{~b}$ & 0.99 \\
\hline \multicolumn{9}{|l|}{ Acids } \\
\hline Acetic Acid & Vinegar & $200^{8}$ & $\begin{array}{l}92.21-1140.29 \\
342.97 \pm 166.01\end{array}$ & $\mathrm{~b}$ & 1.71 & $\begin{array}{l}80.91-1191.02 \\
419.4 \pm 192.58\end{array}$ & a & 2.10 \\
\hline Propionic Acid & Rancid, pungent & $20^{11}$ & $\begin{array}{l}0.73-50.06 \\
7.73 \pm 11.85\end{array}$ & a & 0.39 & $\begin{array}{l}1.12-43.01 \\
6.57 \pm 8.05\end{array}$ & a & 0.33 \\
\hline Isobutyric Acid & Acidic & $2.3^{9}$ & $\begin{array}{l}0.20-2.28 \\
0.89 \pm 0.41\end{array}$ & a & 0.39 & $\begin{array}{l}0.20-2.74 \\
0.98 \pm 0.37\end{array}$ & a & 0.43 \\
\hline Butyric Acid & Rancid, cheese, sweat & $0.173^{9}$ & $\begin{array}{l}1.21-4.34 \\
1.92 \pm 0.49\end{array}$ & a & 11.11 & $\begin{array}{l}0.78-3.81 \\
1.76 \pm 0.57\end{array}$ & $\mathrm{~b}$ & 10.18 \\
\hline Isovaleric Acid & Blue cheese & $0.033^{9}$ & $\begin{array}{l}0.13-1.90 \\
0.77 \pm 0.31\end{array}$ & a & 2.33 & $\begin{array}{l}0.15-2.52 \\
0.82 \pm 0.37\end{array}$ & a & 2.49 \\
\hline Valeric Acid & - & - & $\begin{array}{l}0.10-0.37 \\
0.10 \pm 0.04\end{array}$ & $\mathrm{a}$ & $\mathrm{n} / \mathrm{a}$ & $\begin{array}{l}0.10-0.37 \\
0.10 \pm 0.04\end{array}$ & a & $\mathrm{n} / \mathrm{a}$ \\
\hline Hexanoic Acid & Sweat, cheesy & $0.42^{9}$ & $\begin{array}{l}0.05-10.43 \\
4.97 \pm 1.17\end{array}$ & $\mathrm{~b}$ & 11.83 & $\begin{array}{c}2.85-13.70 \\
5.67 \pm 1.54\end{array}$ & a & 13.49 \\
\hline Octanoic Acid & Rancid, harsh, sweaty & $0.50^{9}$ & $\begin{array}{l}1.15-10.20 \\
4.88 \pm 1.90\end{array}$ & $\mathrm{~b}$ & 9.75 & $\begin{array}{l}1.73-12.24 \\
6.74 \pm 1.79\end{array}$ & $\mathrm{a}$ & 13.49 \\
\hline Decanoic Acid & Rancid, fatty & $1^{9}$ & $\begin{array}{l}0.40-3.04 \\
1.07 \pm 0.50\end{array}$ & $\mathrm{~b}$ & 1.07 & $\begin{array}{l}0.43-5.79 \\
1.75 \pm 0.79\end{array}$ & $\mathrm{a}$ & 1.74 \\
\hline
\end{tabular}

${ }^{1}$ Odour threshold; ${ }^{2}$ Standard deviation; ${ }^{3}$ Odour activity value; ${ }^{4}$ Not applicable; ${ }^{5}$ Mean values with different letters are significantly different between cultivars; ${ }^{6} \mathrm{Peinado} e t$ al., 2004; ${ }^{7}$ Etievant, 1991; ${ }^{8}$ Guth, 1997; ${ }^{9}$ Ferreira et al., 2000; ${ }^{10}$ Ferreira et al., 2001; ${ }^{11}$ Lambrechts and Pretorius., 2000 
acids and esters. This is interesting, as one would expect to see an indirect relationship between the levels of acids and alcohols and their corresponding esters, and not a direct relationship, as in this case.

Chardonnay contained significantly higher amounts of butanol, butyric acid, ethyl butyrate, methanol, propanol, diethyl succinate and ethyl lactate. Both diethyl succinate and ethyl lactate are associated with malolactic fermentation. Chardonnay wines are more commonly subjected to barrel maturation than Sauvignon blanc and therefore undergo malolactic fermentation more frequently. These findings are in agreement with those previously reported for SA Chardonnay (Tredoux et al., 2008). Apart from methanol, the other compounds that were significantly higher in Chardonnay wines were butanol, butyric acid, ethyl butyrate and propanol, which are all biosynthesized from 2-amino butyric acid (Lambrechts and Pretorius, 2000). Of all these compounds,

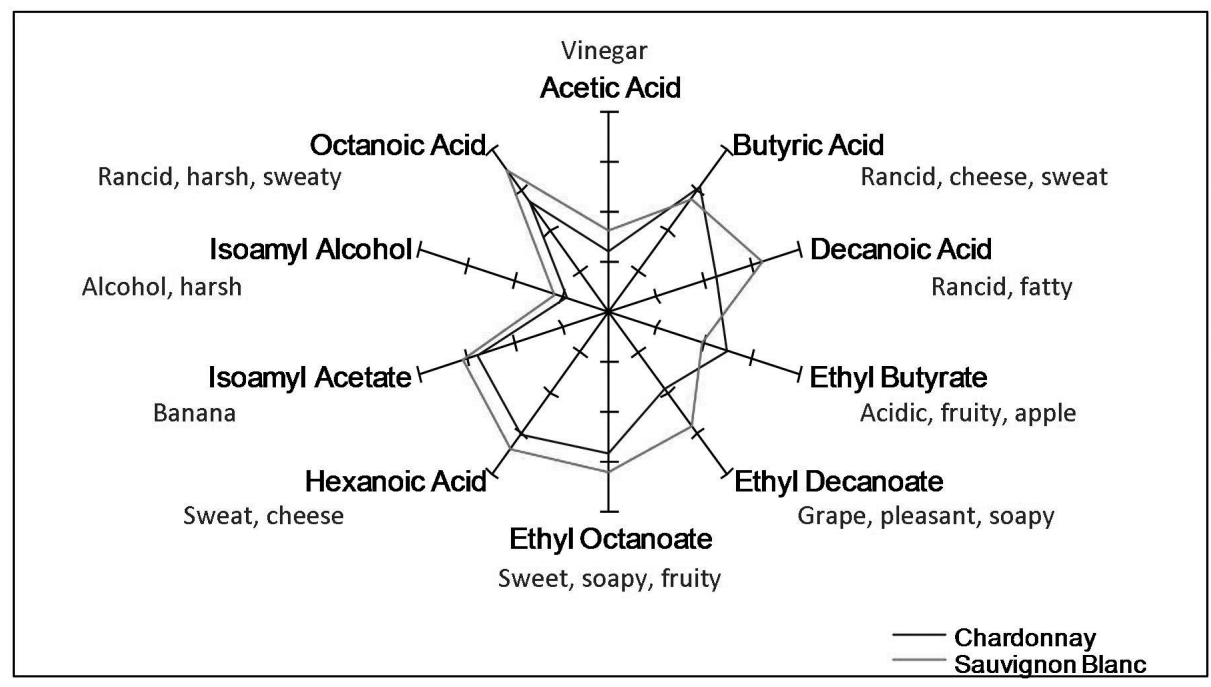

FIGURE 2

An illustration of the differentiation of white wine cultivars based on ten compounds that differed significantly between the wines and occurred above their respective odour threshold values.
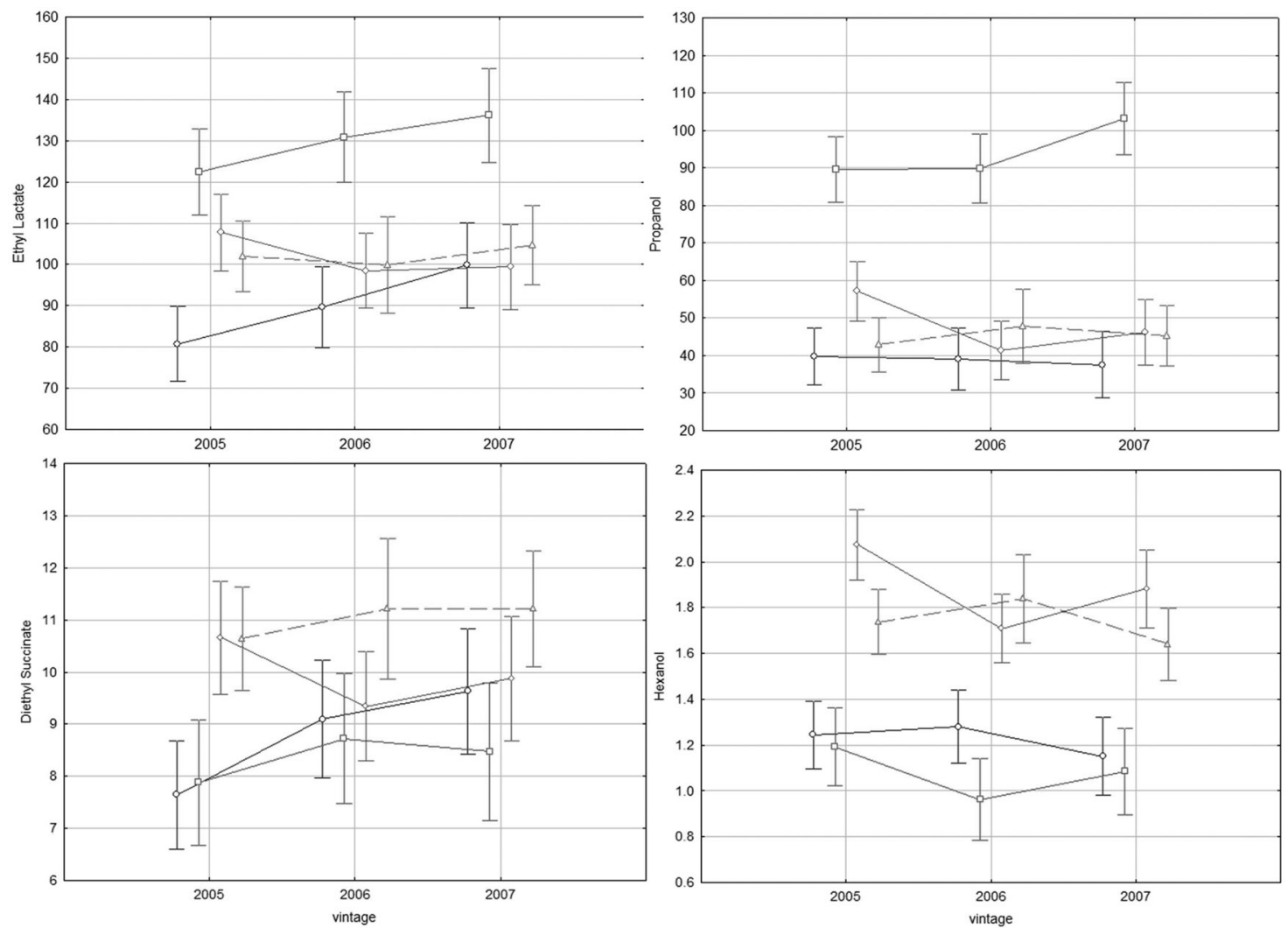

Merlot $\square$ Pinotage $\diamond$ Shiraz $\triangle$ Cabernet Sauvignon

FIGURE 3

Aroma compounds that occurred at consistent levels in South African young red wines over the course of vintages 2005 to 2007. 
only ethyl butyrate and butyric acid were present at odour active concentrations in the white wines.

\section{Fermentation-derived compounds in red cultivars}

The concentration levels of the various compounds present in the four red cultivar wines, along with their odour threshold and odour activity values for each cultivar are listed in Table 5.
Several studies reported on the levles of fermentation-derived volatile compounds in the SA cultivar Pinotage. Van Wyck et al. (1979) reported isoamyl acetate levels in Pinotage ranging from $3.50 \mathrm{mg} / \mathrm{L}$ to $25 \mathrm{mg} / \mathrm{L}$. This range overlaps with the higher end of the range for isoamyl acetate reported for Pinotage wines in this study. Weldegergis and Crouch (2008) used headspace sorptive extraction of volatiles in Pinotage Wines and found significant differences in the volatile composition over two vintages.

TABLE 4

ANOVA p-values indicating whether there were significant vintage and cultivar effects, and vintage*cultivar interactions among the white and red wines, respectively.

\begin{tabular}{|c|c|c|c|c|c|c|}
\hline \multirow[b]{2}{*}{ Compound } & \multicolumn{3}{|c|}{ White wines } & \multicolumn{3}{|c|}{ Red wines } \\
\hline & $\begin{array}{l}\text { Vintage } \\
\left(\mathrm{dF}^{\mathrm{a}}=2\right)\end{array}$ & $\begin{array}{l}\text { Cultivar } \\
(\mathrm{dF}=1)\end{array}$ & $\begin{array}{c}\text { Vintage* } \\
\text { Cultivar }(\mathrm{dF}=2)\end{array}$ & $\begin{array}{l}\text { Vintage } \\
(d F=2)\end{array}$ & $\begin{array}{l}\text { Cultivar } \\
(\mathrm{dF}=3)\end{array}$ & $\begin{array}{c}\text { Vintage* }^{*} \\
\text { Cultivar }(\mathrm{dF}=6)\end{array}$ \\
\hline \multicolumn{7}{|l|}{ Alcohols } \\
\hline Methanol & $<0.001^{\mathrm{b}}$ & $<0.001$ & 0.406 & $<0.001$ & $<0.001$ & $<0.001$ \\
\hline Propanol & 0.497 & $<0.001$ & 0.123 & 0.503 & $<0.001$ & 0.054 \\
\hline Butanol & $<0.001$ & 0.048 & 0.118 & $<0.001$ & $<0.001$ & $<0.001$ \\
\hline Isoamyl Alcohol & 0.127 & $<0.001$ & 0.292 & 0.101 & $<0.001$ & 0.046 \\
\hline Isobutanol & $<0.001$ & 0.002 & 0.160 & $<0.001$ & $<0.001$ & $<0.001$ \\
\hline Hexanol & $<0.001$ & 0.001 & 0.006 & 0.061 & $<0.001$ & 0.060 \\
\hline 2-Phenylethanol & 0.219 & $<0.001$ & 0.628 & 0.649 & $<0.001$ & 0.004 \\
\hline \multicolumn{7}{|l|}{ Esters } \\
\hline Ethyl Acetate & $<0.001$ & 0.956 & 0.164 & 0.663 & $<0.001$ & $<0.001$ \\
\hline Ethyl Butyrate & 0.002 & $<0.001$ & $<0.001$ & $<0.001$ & $<0.001$ & $<0.001$ \\
\hline Isoamyl Acetate & $<0.001$ & 0.010 & 0.012 & 0.086 & $<0.001$ & $<0.001$ \\
\hline Ethyl Hexanoate & 0.206 & 0.384 & $<0.001$ & $<0.001$ & $<0.001$ & $<0.001$ \\
\hline Hexyl Acetate & $<0.001$ & 0.771 & 0.034 & $<0.001$ & $<0.001$ & $<0.001$ \\
\hline Ethyl Lactate & $<0.001$ & 0.004 & 0.280 & 0.149 & $<0.001$ & 0.140 \\
\hline Ethyl Octanoate & $<0.001$ & $<0.001$ & $<0.001$ & $<0.001$ & $<0.001$ & $<0.001$ \\
\hline Ethyl Decanoate & $<0.001$ & $<0.001$ & $<0.001$ & $<0.001$ & 0.044 & 0.006 \\
\hline Diethyl Succinate & $<0.001$ & $<0.001$ & 0.051 & 0.337 & $<0.001$ & 0.164 \\
\hline 2-Phenylethyl Acetate & $<0.001$ & $<0.001$ & $<0.001$ & $<0.001$ & $<0.001$ & $<0.001$ \\
\hline \multicolumn{7}{|l|}{ Acids } \\
\hline Acetic Acid & 0.185 & $<0.001$ & 0.018 & 0.027 & $<0.001$ & 0.036 \\
\hline Propionic Acid & $<0.001$ & 0.117 & 0.272 & $<0.001$ & $<0.001$ & $<0.001$ \\
\hline Isobutyric Acid & $<0.001$ & 0.070 & 0.163 & $<0.001$ & $<0.001$ & 0.218 \\
\hline Butyric Acid & $<0.001$ & $<0.001$ & 0.011 & $<0.001$ & $<0.001$ & 0.543 \\
\hline Isovaleric Acid & $<0.001$ & 0.709 & $<0.001$ & $<0.001$ & $<0.001$ & 0.041 \\
\hline Valeric Acid & 0.001 & 0.802 & 0.925 & $<0.001$ & $<0.001$ & $<0.001$ \\
\hline Hexanoic Acid & 0.688 & $<0.001$ & 0.089 & $<0.001$ & $<0.001$ & 0.008 \\
\hline Octanoic Acid & $<0.001$ & $<0.001$ & $<0.001$ & 0.158 & $<0.001$ & $<0.001$ \\
\hline Decanoic Acid & $<0.001$ & $<0.001$ & $<0.001$ & $<0.001$ & $<0.001$ & $<0.001$ \\
\hline
\end{tabular}

${ }^{a}$ Degree of freedom; ${ }^{b}$-values significant at $\alpha=5 \%$ are indicated in bold. 
Some marked differences were also observed between the results obtained from this study and the results published on the volatile composition of Pinotage and Cabernet Sauvignon wines by Marais et al. in 1981. This earlier study reported significantly lower levels of ethyl lactate $(2.38-10.87 \mathrm{mg} / \mathrm{L})$ and diethyl succinate $(0.28$ - $3.28 \mathrm{mg} / \mathrm{L}$ ) in both Pinotage and Cabernet Sauvignon wines (Marais et al., 1981 a). In comparison, the average concentration of ethyl lactate in Pinotage and Cabernet Sauvignon wines in this study was $129 \mathrm{mg} / \mathrm{L}$ and $102 \mathrm{mg} / \mathrm{L}$ respectively (Table 5), while the average concentration for diethyl succinate was respectively, 8.30 $\mathrm{mg} / \mathrm{L}$ and $10.96 \mathrm{mg} / \mathrm{L}$ for the Pinotage and Cabernet Sauvignon wines. Ethyl lactate and diethyl succinate are both by-products of malolactic fermentation and the differences in concentrations reported by Marais et al., in 1981 and those reported in this study, may be a reflection of different MLF regimes applied.

Data published by Gil et al. (2006) showed that levels of fermentation-derived compounds in Spanish wines are very similar to the levels obtained for the red wines in this study, although pertaining to different red cultivars. Some exceptions are lower levels of hexyl acetate (trace levels) and propanol $(29.50 \mathrm{mg} / \mathrm{L})$ and higher levels of butyric acid $(4.77 \mathrm{mg} / \mathrm{L})$ in the Spanish wines (Gil et al., 2006). Another publication on Spanish wines by Viviani et al. (2007) reported on the volatile composition of Shiraz. Apart from much higher levels of diethyl succinate (40 $\mathrm{mg} / \mathrm{L})$, the results that they reported were very similar to the results from this study.

The volatile composition of Cabernet Sauvignon wines from China (Zhang et al., 2007) had significantly different concentration levels to those found in this study. However, for isoamyl alcohol, hexyl acetate, diethyl succinate, 2-phenylethyl acetate and hexanoic acid similar concentration levels were reported. In addition, lower levels for butanol $(0.82 \mathrm{mg} / \mathrm{L})$, hexanol $(0.99 \mathrm{mg} / \mathrm{L})$, 2-phenylethanol $(24.16 \mathrm{mg} / \mathrm{L})$, ethyl acetate $(35.78 \mathrm{mg} / \mathrm{L})$, ethyl lactate $(24.41 \mathrm{mg} / \mathrm{L})$, isobutyric acid $(0.26 \mathrm{mg} / \mathrm{L})$ and octanoic acid $(0.78 \mathrm{mg} / \mathrm{L})$ were found (compare to Table 5$)$. In addition, Zhang et al. also reported higher levels of ethyl butyrate $(4.50 \mathrm{mg} / \mathrm{L})$, isoamyl acetate $(18.33 \mathrm{mg} / \mathrm{L})$, ethyl octanoate $(14.33 \mathrm{mg} / \mathrm{L})$, ethyl decanoate $(3.33 \mathrm{mg} / \mathrm{L})$ and acetic acid $(949.54 \mathrm{mg} / \mathrm{L})$.

\section{Variation over vintages 2005 to 2007}

The average concentrations of hexanol, propanol, diethyl succinate and ethyl lactate did not change over the vintages investigated (Figure 3) and the concentration ranges reported in this study can be considered as being typical for SA Pinotage, Cabernet Sauvignon, Merlot and Shiraz young wines. Interestingly, Ferreira et al. (2000) found that, in contrast to the results from this study, the hexanol concentration of young red Spanish wines (including Merlot and Cabernet Sauvignon), did differ over vintage.

Butyric acid and isobutyric acid differed over vintage and followed the same trend in all four red cultivars (Table 4). As before, the results from this study were different to that of Ferreira et al. (2000) in which no significant vintage effect in isobutyric acid concentration was observed. The lack of similarities between the study of Ferreira et al. and this study, could suggest that the SA wines may have a larger variability over vintages than Spanish wines, although this cannot be confirmed as yet. Several compounds analysed in this study were not investigated by Ferreira et al. Nevertheless, of the 8 compounds that showed different results, only four (ethyl hexanoate, ethyl octanoate,

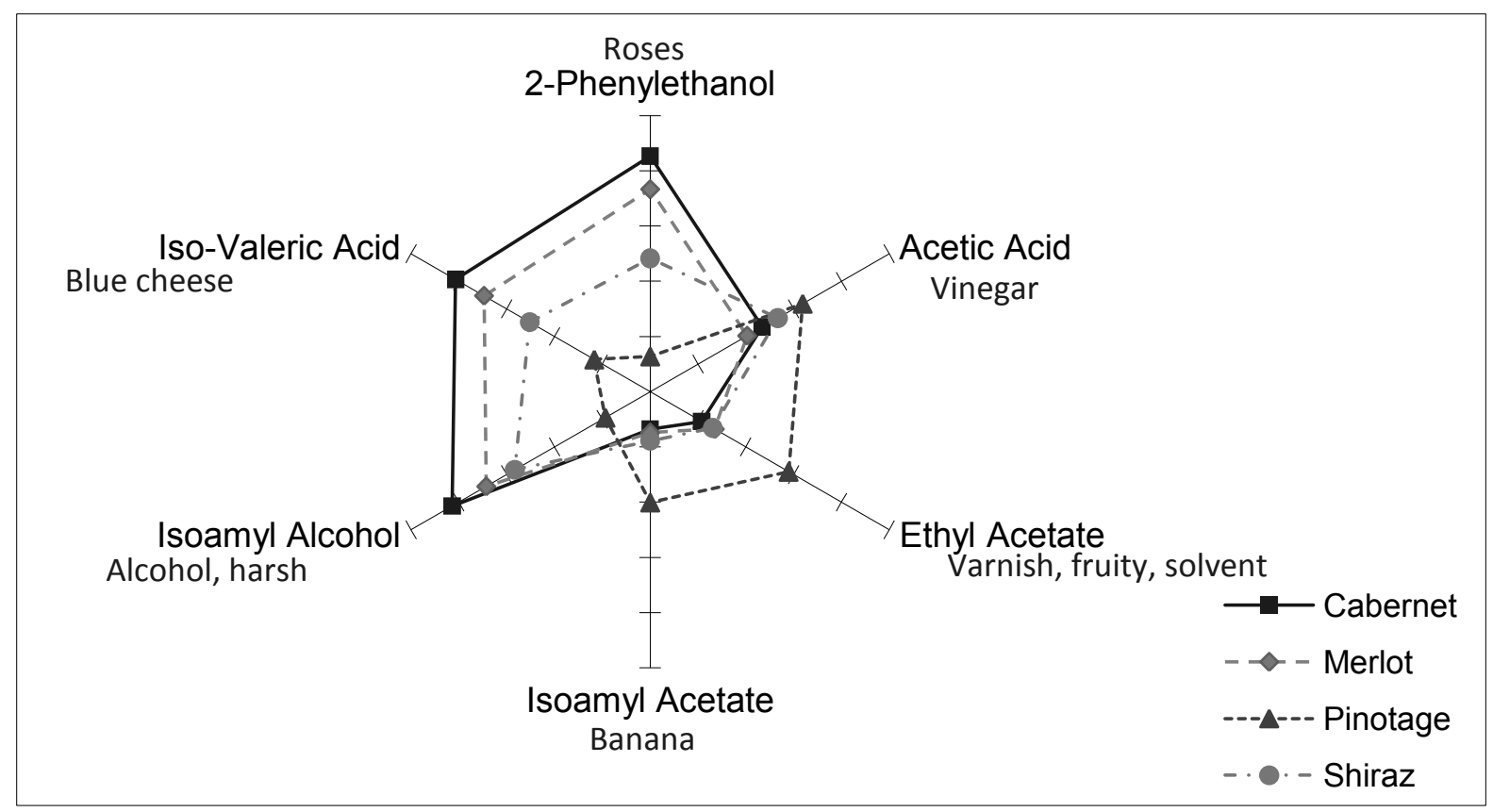

FIGURE 4

An illustration of the differentiation between four red wine cultivars in terms of selected odour active compounds. 
TABLE 5

Volatile composition of young SA red wines studied.

\begin{tabular}{|c|c|c|c|c|c|c|c|c|c|c|c|c|c|}
\hline \multirow{2}{*}{ Analyte } & \multirow{2}{*}{$\begin{array}{l}\mathrm{OTH}^{1} \\
(\mathrm{mg} / \mathrm{L})\end{array}$} & \multicolumn{3}{|c|}{ Merlot (n=162) } & \multicolumn{3}{|c|}{ Pinotage $(n=129)$} & \multicolumn{3}{|c|}{ Shiraz $(n=167)$} & \multicolumn{3}{|c|}{ Cabernet Sauvignon $(\mathrm{n}=161)$} \\
\hline & & $\begin{array}{r}\text { Minimum-maximur } \\
\text { Mean } \pm \mathbf{S D}^{2}(\mathrm{mg} / \mathrm{L}\end{array}$ & & $\mathbf{O A V} \mathbf{V}^{3}$ & $\begin{array}{r}\text { Minimum-maximur } \\
\text { Mean } \pm \text { SD }(m g / L) \\
\end{array}$ & & OAV & $\begin{array}{c}\text { Minimum-maximun } \\
\text { Mean } \pm \text { SD }(m g / L)\end{array}$ & & OAV & $\begin{array}{r}\text { Minimum-maximu } \\
\text { Mean } \pm \text { SD }(\mathbf{m g} / \mathbf{L})\end{array}$ & & OAV \\
\hline \multicolumn{7}{|l|}{ Alcohols } & & & & & & & \\
\hline Methanol & - & $\begin{array}{l}89.21-406.66 \\
237.83 \pm 58.51\end{array}$ & $a^{4}$ & $\mathrm{n} / \mathrm{a}^{5}$ & $\begin{array}{l}44.19-284.80 \\
147.99 \pm 39.74\end{array}$ & d & $\mathrm{n} / \mathrm{a}$ & $\begin{array}{l}76.18-439.06 \\
222.47 \pm 74.22\end{array}$ & $\mathrm{~b}$ & $\mathrm{n} / \mathrm{a}$ & $\begin{array}{l}79.80-407.95 \\
193.45 \pm 59.02\end{array}$ & $\mathrm{c}$ & $\mathrm{n} / \mathrm{a}$ \\
\hline Propanol & $306^{6}$ & $\begin{array}{c}9.09-97.47 \\
38.92 \pm 17.98\end{array}$ & $\mathrm{c}$ & 0.13 & $\begin{array}{l}4.81-285.91 \\
93.79 \pm 49.27\end{array}$ & $\mathrm{a}$ & 0.31 & $\begin{array}{l}3.55-178.40 \\
48.30 \pm 29.37\end{array}$ & $\mathrm{~b}$ & 0.16 & $\begin{array}{l}3.29-155.10 \\
44.85 \pm 21.33\end{array}$ & bc & 0.15 \\
\hline Butanol & $150^{7}$ & $\begin{array}{l}0.96-3.53 \\
1.82 \pm 0.48\end{array}$ & $\mathrm{a}$ & 0.01 & $\begin{array}{l}0.20-4.44 \\
1.58 \pm 0.84\end{array}$ & $\mathrm{~b}$ & 0.01 & $\begin{array}{l}0.20-3.57 \\
1.80 \pm 0.68\end{array}$ & $\mathrm{a}$ & 0.01 & $\begin{array}{l}0.91-5.00 \\
1.90 \pm 0.61\end{array}$ & $\mathrm{a}$ & 0.01 \\
\hline Isoamyl Alcohol & $40^{8}$ & $\begin{array}{l}174.43-643.33 \\
342.98 \pm 85.44\end{array}$ & $\mathrm{~b}$ & 11.43 & $\begin{array}{l}98.08-331.12 \\
210.91 \pm 40.98\end{array}$ & d & 7.03 & $\begin{array}{l}174.34-603.35 \\
311.26 \pm 62.46\end{array}$ & $\mathrm{c}$ & 10.38 & $\begin{array}{l}159.49-625.79 \\
380.90 \pm 76.02\end{array}$ & a & 12.70 \\
\hline Isobutanol & $30^{8}$ & $\begin{array}{c}18.63-124.30 \\
59.00 \pm 16.16\end{array}$ & $\mathrm{a}$ & 1.48 & $\begin{array}{c}3.40-62.00 \\
30.22 \pm 17.53\end{array}$ & $\mathrm{c}$ & 0.76 & $\begin{array}{l}4.26-134.35 \\
39.03 \pm 25.97\end{array}$ & b & 0.98 & $\begin{array}{l}2.34-115.89 \\
37.69 \pm 29.41\end{array}$ & $\mathrm{~b}$ & 0.94 \\
\hline Hexanol & $8^{8}$ & $\begin{array}{l}0.26-4.39 \\
1.23 \pm 0.55\end{array}$ & $\mathrm{c}$ & 0.15 & $\begin{array}{l}0.18-2.35 \\
1.08 \pm 0.39\end{array}$ & d & 0.14 & $\begin{array}{l}0.36-5.47 \\
1.88 \pm 0.78\end{array}$ & $\mathrm{a}$ & 0.24 & $\begin{array}{c}0.68-5.36 \\
1.73 \pm 0.59\end{array}$ & $\mathrm{~b}$ & 0.22 \\
\hline 2-Phenylethanol & $14^{9}$ & $\begin{array}{c}10.14-155.41 \\
59.92 \pm 24.11\end{array}$ & $\mathrm{~b}$ & 4.28 & $\begin{array}{l}7.58-47.35 \\
17.59 \pm 6.21\end{array}$ & d & 1.26 & $\begin{array}{l}14.31-96.27 \\
42.44 \pm 15.62\end{array}$ & c & 3.03 & $\begin{array}{c}24.47-142.14 \\
68.37 \pm 24.71\end{array}$ & a & 4.88 \\
\hline \multicolumn{14}{|l|}{ Esters } \\
\hline Ethyl Acetate & $12.26^{10}$ & $\begin{array}{c}27.74-145.54 \\
68.66 \pm 18.64\end{array}$ & $\mathrm{~b}$ & 5.60 & $\begin{array}{c}29.32-183.58 \\
89.05 \pm 25.40\end{array}$ & $\mathrm{a}$ & 7.26 & $\begin{array}{c}20.19-157.07 \\
68.14 \pm 19.87\end{array}$ & b & 5.56 & $\begin{array}{c}32.10-125.67 \\
65.06 \pm 16.56\end{array}$ & $\mathrm{~b}$ & 5.31 \\
\hline Ethyl Butyrate & $0.02^{8}$ & $\begin{array}{l}0.06-1.85 \\
0.19 \pm 0.20\end{array}$ & $\mathrm{c}$ & 9.26 & $\begin{array}{l}0.06-7.26 \\
0.29 \pm 0.63\end{array}$ & $\mathrm{~b}$ & 14.49 & $\begin{array}{l}0.06-4.44 \\
0.42 \pm 0.68\end{array}$ & $\mathrm{a}$ & 20.77 & $\begin{array}{c}0.06-2.00 \\
0.14 \pm 0.16\end{array}$ & $\mathrm{c}$ & 7.13 \\
\hline Isoamyl Acetate & $0.03^{8}$ & $\begin{array}{l}0.19-4.67 \\
1.19 \pm 0.72\end{array}$ & $\mathrm{bc}$ & 39.66 & $\begin{array}{l}0.31-10.49 \\
2.80 \pm 1.86\end{array}$ & $\mathrm{a}$ & 93.45 & $\begin{array}{l}0.22-5.84 \\
1.38 \pm 0.75\end{array}$ & $\mathrm{~b}$ & 46.04 & $\begin{array}{c}0.05-5.83 \\
1.12 \pm 0.76\end{array}$ & $\mathrm{c}$ & 37.20 \\
\hline Ethyl Hexanoate & $0.014^{9}$ & $\begin{array}{l}0.07-1.01 \\
0.61 \pm 0.28\end{array}$ & $\mathrm{a}$ & 43.27 & $\begin{array}{l}0.07-1.31 \\
0.57 \pm 0.34\end{array}$ & $\mathrm{a}$ & 40.71 & $\begin{array}{l}0.07-1.03 \\
0.38 \pm 0.37\end{array}$ & $\mathrm{c}$ & 27.43 & $\begin{array}{c}0.07-1.16 \\
0.46 \pm 0.32\end{array}$ & $\mathrm{~b}$ & 33.08 \\
\hline Hexyl Acetate & $1.5^{7}$ & $\begin{array}{l}0.00-0.52 \\
0.11 \pm 0.13\end{array}$ & $\mathrm{c}$ & 0.08 & $\begin{array}{l}0.07-1.63 \\
0.20 \pm 0.27\end{array}$ & $\mathrm{a}$ & 0.13 & $\begin{array}{l}0.07-1.06 \\
0.23 \pm 0.25\end{array}$ & $\mathrm{a}$ & 0.15 & $\begin{array}{l}0.07-0.53 \\
0.16 \pm 0.16\end{array}$ & $\mathrm{~b}$ & 0.10 \\
\hline Ethyl Lactate & $154.6^{10}$ & $\begin{array}{l}4.13-194.67 \\
89.21 \pm 32.70\end{array}$ & $\mathrm{c}$ & 0.58 & $\begin{array}{l}35.75-402.15 \\
129.37 \pm 46.62\end{array}$ & $\mathrm{a}$ & 0.84 & $\begin{array}{l}23.54-214.24 \\
101.94 \pm 36.24\end{array}$ & $\mathrm{~b}$ & 0.66 & $\begin{array}{l}19.64-194.70 \\
102.36 \pm 30.49\end{array}$ & $\mathrm{~b}$ & 0.66 \\
\hline Ethyl Octanoate & $0.005^{9}$ & $\begin{array}{l}0.06-0.80 \\
0.29 \pm 0.18\end{array}$ & $\mathrm{a}$ & 57.37 & $\begin{array}{l}0.06-0.87 \\
0.30 \pm 0.16\end{array}$ & $\mathrm{a}$ & 59.14 & $\begin{array}{l}0.06-0.42 \\
0.14 \pm 0.08\end{array}$ & b & 27.93 & $\begin{array}{l}0.06-0.56 \\
0.15 \pm 0.08\end{array}$ & $\mathrm{~b}$ & 29.27 \\
\hline Ethyl Decanoate & $0.2^{9}$ & $\begin{array}{l}0.23-0.59 \\
0.24 \pm 0.04\end{array}$ & $a b$ & 1.20 & $\begin{array}{l}0.23-0.45 \\
0.24 \pm 0.03\end{array}$ & $\mathrm{ab}$ & 1.18 & $\begin{array}{l}0.23-1.18 \\
0.25 \pm 0.14\end{array}$ & $\mathrm{a}$ & 1.27 & $\begin{array}{l}0.23-0.23 \\
0.23 \pm 0.00\end{array}$ & $\mathrm{~b}$ & 1.14 \\
\hline $\begin{array}{l}\text { Diethyl } \\
\text { Succinate }\end{array}$ & $200^{7}$ & $\begin{array}{l}1.03-17.73 \\
8.69 \pm 3.89\end{array}$ & $\mathrm{c}$ & 0.04 & $\begin{array}{l}0.69-22.30 \\
8.34 \pm 4.14\end{array}$ & $\mathrm{c}$ & 0.04 & $\begin{array}{l}1.21-20.78 \\
9.95 \pm 4.33\end{array}$ & $\mathrm{~b}$ & 0.05 & $\begin{array}{l}1.94-31.80 \\
10.97 \pm 4.40\end{array}$ & $\mathrm{~b}$ & 0.05 \\
\hline $\begin{array}{l}\text { 2-Phenyl-ethyl } \\
\text { Acetate }\end{array}$ & $0.25^{8}$ & $\begin{array}{l}0.04-0.84 \\
0.10 \pm 0.10\end{array}$ & $\mathrm{c}$ & 0.41 & $\begin{array}{l}0.04-0.48 \\
0.14 \pm 0.12\end{array}$ & $\mathrm{~b}$ & 0.56 & $\begin{array}{l}0.04-0.97 \\
0.13 \pm 0.14\end{array}$ & $\mathrm{~b}$ & 0.53 & $\begin{array}{c}0.04-1.31 \\
0.23 \pm 0.15\end{array}$ & $\mathrm{a}$ & 0.91 \\
\hline \multicolumn{14}{|l|}{ Acids } \\
\hline Acetic Acid & $200^{8}$ & $\begin{array}{l}39.84-1324.16 \\
483.98 \pm 167.38\end{array}$ & $\mathrm{c}$ & 2.42 & $\begin{array}{l}246.69-1280.05 \\
586.50 \pm 146.87\end{array}$ & $\mathrm{a}$ & 2.93 & $\begin{array}{l}225.27-945.58 \\
540.48 \pm 142.12\end{array}$ & $\mathrm{~b}$ & 2.70 & $\begin{array}{l}230.04-882.61 \\
511.78 \pm 130.02\end{array}$ & $\mathrm{bc}$ & 2.56 \\
\hline Propionic Acid & $20^{11}$ & $\begin{array}{l}1.65-149.00 \\
26.00 \pm 31.85\end{array}$ & $\mathrm{a}$ & 1.30 & $\begin{array}{l}1.69-127.61 \\
13.14 \pm 25.03\end{array}$ & $\mathrm{~b}$ & 0.66 & $\begin{array}{l}1.91-17.44 \\
4.61 \pm 3.52\end{array}$ & $\mathrm{c}$ & 0.23 & $\begin{array}{l}0.76-16.45 \\
2.96 \pm 1.96\end{array}$ & $\mathrm{c}$ & 0.15 \\
\hline Isobutyric Acid & $2.3^{9}$ & $\begin{array}{l}0.62-7.31 \\
2.08 \pm 0.81\end{array}$ & $\mathrm{a}$ & 0.91 & $\begin{array}{l}0.35-2.99 \\
1.45 \pm 0.52\end{array}$ & $\mathrm{~b}$ & 0.63 & $\begin{array}{l}0.54-5.34 \\
1.95 \pm 0.83\end{array}$ & $\mathrm{a}$ & 0.85 & $\begin{array}{l}0.80-7.79 \\
2.03 \pm 0.84\end{array}$ & $\mathrm{a}$ & 0.88 \\
\hline Butyric Acid & $0.173^{9}$ & $\begin{array}{l}0.40-2.44 \\
1.02 \pm 0.33\end{array}$ & $\mathrm{~b}$ & 5.87 & $\begin{array}{l}0.60-3.35 \\
1.30 \pm 0.38\end{array}$ & $a$ & 7.52 & $\begin{array}{l}0.38-2.61 \\
1.01 \pm 0.32\end{array}$ & $\mathrm{~b}$ & 5.83 & $\begin{array}{l}0.07-2.17 \\
0.97 \pm 0.28\end{array}$ & $\mathrm{~b}$ & 5.60 \\
\hline Isovaleric Acid & $0.033^{9}$ & $\begin{array}{c}.80-7.98 \\
2.54 \pm 1.05\end{array}$ & $\mathrm{~b}$ & 7.69 & $\begin{array}{l}0.37-2.60 \\
1.31 \pm 0.43\end{array}$ & d & 3.98 & $\begin{array}{l}0.75-3.80 \\
2.03 \pm 0.61\end{array}$ & $\mathrm{c}$ & 6.15 & $\begin{array}{l}0.86-7.68 \\
2.85 \pm 0.91\end{array}$ & $\mathrm{a}$ & 8.64 \\
\hline Valeric acid & - & $\begin{array}{l}0.10-1.63 \\
0.27 \pm 0.31\end{array}$ & $a$ & $\mathrm{n} / \mathrm{a}$ & $\begin{array}{l}0.10-0.79 \\
0.17 \pm 0.11\end{array}$ & b & $\mathrm{n} / \mathrm{a}$ & $\begin{array}{l}0.10-0.32 \\
0.10 \pm 0.03\end{array}$ & $\mathrm{c}$ & $\mathrm{n} / \mathrm{a}$ & $\begin{array}{l}0.10-0.47 \\
0.13 \pm 0.06\end{array}$ & $\mathrm{c}$ & $\mathrm{n} / \mathrm{a}$ \\
\hline Hexanoic Acid & $0.42^{9}$ & $\begin{array}{l}0.54-2.85 \\
1.44 \pm 0.47\end{array}$ & $\mathrm{~b}$ & 3.43 & $\begin{array}{l}0.84-4.53 \\
1.96 \pm 0.66\end{array}$ & $\mathrm{a}$ & 4.67 & $\begin{array}{l}0.05-3.20 \\
1.45 \pm 0.47\end{array}$ & $\mathrm{~b}$ & 3.45 & $\begin{array}{l}0.05-3.95 \\
1.52 \pm 0.46\end{array}$ & $\mathrm{~b}$ & 3.63 \\
\hline Octanoic Acid & $0.50^{9}$ & $\begin{array}{l}0.28-3.33 \\
1.67 \pm 0.57\end{array}$ & $\mathrm{~b}$ & 3.34 & $\begin{array}{l}0.70-4.47 \\
1.91 \pm 0.73\end{array}$ & $\mathrm{a}$ & 3.83 & $\begin{array}{l}0.35-3.95 \\
1.34 \pm 0.57\end{array}$ & d & 2.67 & $\begin{array}{l}0.62-3.77 \\
1.47 \pm 0.51\end{array}$ & $\mathrm{c}$ & 2.94 \\
\hline Decanoic Acid & $1^{9}$ & $\begin{array}{l}0.12-1.76 \\
0.76 \pm 0.50\end{array}$ & $a$ & 0.76 & $\begin{array}{l}0.12-1.79 \\
0.69 \pm 0.42\end{array}$ & $\mathrm{~b}$ & 0.69 & $\begin{array}{l}0.12-1.04 \\
0.42 \pm 0.24\end{array}$ & d & 0.42 & $\begin{array}{c}0.12-1.08 \\
0.64 \pm 0.32\end{array}$ & $\mathrm{c}$ & 0.64 \\
\hline
\end{tabular}

${ }^{1}$ Odour threshold; ${ }^{2}$ Standard deviation; ${ }^{3}$ Odour activity value; ${ }^{4}$ Mean values with different letters are significantly different between cultivars; ${ }^{6}$ Not applicable ; ${ }^{6}$ Peinado $e t$ al., 2004; ${ }^{7}$ Etievant, 1991; ${ }^{8}$ Guth, 1997; ${ }^{9}$ Ferreira et al., 2000; ${ }^{10}$ Ferreira et al., 2001; ${ }^{11}$ Lambrechts and Pretorius, 2000. 


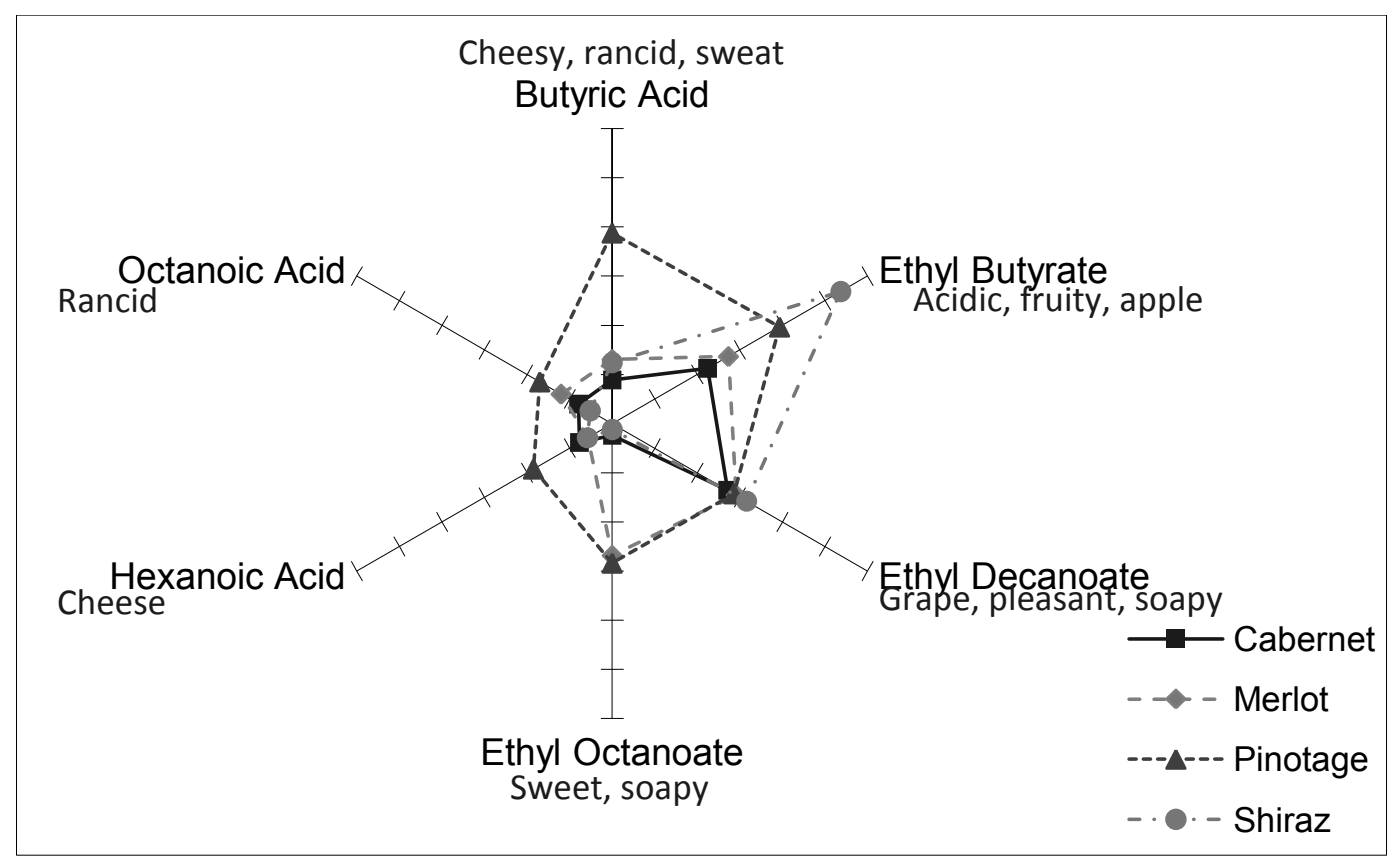

FIGURE 5

An illustration of the relative concentration levels at which odour active fatty acids and their ethyl esters occur in four red cultivar wines.

acetic acid and hexanoate) occurred at odour active quantities in the SA wines.

Some compounds changed over vintage, but in different ways for each of the red wine cultivars. These were: butanol, isobutanol, methanol, 2-phenyl acetate, ethyl hexanoate, ethyl butyrate, ethyl decanoate, ethyl octanoate, hexyl acetate, acetic acid, decanoic acid, hexanoic acid, isovaleric acid, propionic acid and valeric acid. Of these, Ferreira et al., also found 2-phenyl acetate and isovaleric acid to change significantly over vintages.

\section{Differentiation between cultivars}

Significant differences were observed between the red wine cultivars for all the volatile compounds that were analysed (Table 5). Twelve of the compounds were present above their odour threshold values in all of the red wines. All of these compounds were also reported to occur above their odour thresholds in Spanish red wines (Ferreira et al. 2000). Two compounds, isobutanol and propionic acid, were present above their odour thresholds in Merlot wines only. The differentiation between the four cultivars in terms of the odour active compounds is illustrated in Figure 4 and Figure 5.

Cabernet Sauvignon wines contained the highest levels of 2-phenylethyl acetate, diethyl succinate, isoamyl alcohol and isovaleric acid. Furthermore, this cultivar contained the lowest levels of propionic acid and ethyl hexanoate. Merlot wines differentiated from the rest of the wines based on higher levels of valeric acid, propionic acid, ethyl hexanoate, ethyl octanoate, isobutyric acid, isobutanol and methanol. In addition, the Merlot wines contained significantly lower concentrations of propanol, 2-phenylethyl acetate, diethyl succinate, ethyl lactate and hexyl acetate. Pinotage wines differed from the other red wines in terms of significantly lower levels of isobutyric acid, isobutanol, methanol, isovaleric acid, butanol, diethyl succinate, hexanol and isoamyl alcohol. However, the Pinotage wines had the highest concentration of octanoic acid, propanol, ethyl hexanoate, ethyl octanoate, ethyl lactate and isoamyl acetate. Shiraz wines contained the highest amounts of hexanol and hexyl acetate and the lowest levels of octanoic acid and valeric acid.

Unlike the white wines, there did not seem to be an obvious correlation between the compounds that differentiated a specific red cultivar from the rest of the wines. Merlot wines contained significantly lower amounts of diethyl succinate and ethyl lactate which are both associated with malolactic fermentation. Pinotage contained the highest amounts of octanoic acid and its ethyl ester, ethyl octanoate. This cultivar also had the least amount of isoamyl alcohol, but the highest levels of its acetate ester, isoamyl acetate. The highest amounts of hexanol and its acetate ester were found in Shiraz wines. Therefore, the trend that was observed among the white wines regarding the direct relationship between the esters and their corresponding acids and alcohols did not seem to be as prominent among the red wines cultivars.

\section{Classification of cultivar wines by means of discriminant analysis}

\section{Classification of white wines}

Two subsets of volatile compounds were used to classify the white wine cultivars, Chardonnay and Sauvignon blanc, by means of discriminant analysis (Table 6). The first set, "best subset", was defined as the set of volatile compounds selected by the genetic algorithms selection method that best discriminated between the white wines. The second set, "most used subset" was defined as a compilation of the volatile compounds that occurred in at least 16 of the 21 best subsets generated with the genetic algorithm method.

Discriminant analysis with the "best subset" resulted in the highest total correct classification rate (See Table 7). However, when using the "most used subset", the total correct classification rate dropped with only $1 \%$, which was due to a slightly lower classification success rate for Chardonnay wines. Considering 
TABLE 6

The variables sets used for the discriminant analysis of the white and red wines. In each case, the first sub-column refers to the best subset of variables selected with a genetic algorithm selection method. The second sub-column refers to all the compounds that occurred in 16 or more of the 21 best subsets generated with the genetic algorithm method for the discrimination between the wines.

\begin{tabular}{|c|c|c|c|}
\hline \multicolumn{2}{|c|}{ White wines } & \multicolumn{2}{|c|}{ Red wines } \\
\hline Best subset & Most used subset & Best subset & Most used subset \\
\hline 2-Phenylethanol & 2-Phenylethanol & 2-Phenylethyl Acetate & 2-Phenylethyl Acetate \\
\hline 2-Phenylethyl Acetate & Decanoic Acid & Decanoic Acid & Butanol \\
\hline Acetic Acid & Diethyl Succinate & Diethyl Succinate & Diethyl Succinate \\
\hline Butanol & Ethyl Hexanoate & Ethyl Hexanoate & Ethyl Hexanoate \\
\hline Decanoic Acid & Ethyl Decanoate & Ethyl Decanoate & Ethyl Octanoate \\
\hline Diethyl Succinate & Ethyl Octanoate & Ethyl Octanoate & Ethyl Lactate \\
\hline Ethyl Hexanoate & Hexyl Acetate & Ethyl Lactate & Hexanol \\
\hline Ethyl Acetate & Propanol & Hexanol & Hexyl Acetate \\
\hline Ethyl Decanoate & & Hexyl Acetate & Isoamyl Acetate \\
\hline Ethyl Octanoate & & Isoamyl Acetate & Isoamyl Alcohol \\
\hline Hexanol & & Isoamyl Alcohol & Isobutanol \\
\hline Hexyl Acetate & & Isobutanol & Isobutyric Acid \\
\hline Isoamyl Acetate & & Isobutyric Acid & Isovaleric Acid \\
\hline Isoamyl Alcohol & & Methanol & Methanol \\
\hline Isobutanol & & Octanoic Acid & Propanol \\
\hline Methanol & & Propanol & Propionic Acid \\
\hline Propanol & & Propionic Acid & Valeric Acid \\
\hline Propionic Acid & & Valeric Acid & \\
\hline Valeric Acid & & & \\
\hline
\end{tabular}

that the second model makes use of only 8 variables, while the first one relies on 19 variables, this difference is insignificant. The "most used subset" model is likely to be a more robust model that would have a better chance of getting a similar success rate using a completely new set of SA Chardonnay and Sauvignon blanc wines, compared to the "best subset" model.

From a metabolic point of view it is unclear why these specific compounds would play a more important role in differentiation than the other compounds, but it should be kept in mind that that the selection of several volatile compounds by the genetic algorithm, clearly point to a multivariate phenomenon. The apparent lack of commonalities between the compounds used in the "most used" model, may serve as additional evidence to the robustness of the "most used" model.

\section{Classification of red wines}

The subset of volatile compounds that was included in the most successful genetic algorithm solution is listed as "best subset" in Table 6. This set of variables resulted in a total classification success rate of $74 \%$ for the discriminant analysis of the four red cultivars (Table 7). The Pinotage classifier had the highest percentage correct classification, while the Cabernet Sauvignon classifier performed less satisfactory.

\section{TABLE 7}

Percentage correct classifications (per cultivar and in total) obtained with linear discriminant analysis of SA young cultivar wines using subsets of volatile compounds as selected with a genetic algorithm selection method.

\begin{tabular}{lcc}
\hline \multicolumn{2}{c}{ Red cultivars } & \\
\hline "Best" subset & "Most used" subset \\
\hline Merlot & 74 & 82 \\
Pinotage & 94 & 88 \\
Shiraz & 71 & 75 \\
Cabernet & 65 & 73 \\
Total correct classifications & 74 & 79 \\
\hline & White cultivars & "Most used" subset \\
\hline "Best" subset & 74 \\
\hline Chardonnay & 78 & 92 \\
Sauvignon blanc & 92 & 85 \\
\hline Total correct classifications & 86 & "
\end{tabular}


When the variables that occurred in 16 or more of the genetic algorithm solutions (refer to "most used subset" in Table 6) were compiled and used to discriminate between the red wines, the total classification success rate increased to $79 \%$ (Table 7). The percentage correctly classified Cabernet Sauvignon wines increased with $8 \%$. However, the percentage correctly classified Pinotage wines dropped with $6 \%$.

Unlike the case of the white wines, the "most used" model used only one variable less than the "best subset" model. The major difference between the first model and the second model is that the latter includes the compounds butanol and isovaleric acid and not decanoic acid, ethyl octanoate and octanoic acid.

The "most used" subsets of red wine model included methanol, which was not used for the classification of the white wines. The white wine model made use of 2-phenylethanol, a compound that imparts a floral, honey character, to discriminate between the two white wines. This compound was not used to discriminate between the red wines. The "most-used" subset for the white wine model mostly consisted of esters which are the major fermentation by-product during white wine fermentation (Lambrechts and Pretorius, 2000). White wines are generally fermented at cooler temperatures that promote ester production. On the other hand, the red wine "most used" subset included several higher alcohols, in addition to esters. The higher fermentation temperatures that are often found during red wine vinification promote the production of higher alcohols. The inclusion of a larger number of higher alcohols in the red wine model suggests that higher alcohols are not only more abundant in red wines than white wines, but also more important for the discrimination between red wines than for the discrimination between white wines.

Tredoux et al. (2008) also applied linear discriminant analysis for the classification of SA red wine and white wine cultivars. In a sample set that included Ruby Cabernet amongst red wines and Chenin blanc amongst white wines, esters, alcohols, fatty acids, ketones, volatile phenols and aldehydes were used as variables in the classification model. Correct classification rates of $100 \%$ for respectively red and white cultivars using this combination of compounds, were reported. It is well known that compounds other than alcohols, esters and fatty acids contribute to unique cultivar characteristics and may therefore contribute to a stronger classification model. Indeed, in a recent paper (Louw et al., 2009), it was found that discriminant models using fermentation volatiles improved when used in conjunction with infrared spectral data of the wines under investigation. Spectral data, being of highly multivariate nature, provide a wealth of non-specific compositional information and can be useful to provide complementary data for targeted analytical methods such as the GC-FID analysis used in this study (Skov et al., 2008).

There were striking similarities in the compounds that were considered strong discriminators between red wine cultivars in this study (Table 6) and those reported by Tredoux et al. (2008). The latter study also showed that isoamyl alcohol, 1-hexanol, propionic acid, octanoic acid, isoamyl acetate, 2-phenylethyl acetate and diethyl succinate were important discriminators between red wine cultivars. However, among the list of compounds that were common to both studies, only diethyl succinate and butanol were found to be useful discriminators between white wines by both reports. Interestingly, the results reported by Tredoux et al. confirmed the finding in this study that more compounds were required for discrimination between red wines than between white wines, although more red wine cultivars $(n=5)$ than white wine cultivars $(\mathrm{n}=3)$ were used in modelling (Tredoux et al., 2008).

\section{CONCLUSIONS}

The results of this study provided an overview of the distribution of fermentation-derived volatile compounds in SA young wines. In general, the concentration ranges of the volatile compounds investigated in this study compared well to that reported in the literature. Due to the significant vintage to vintage changes in the volatile composition of the wines, it was not considered feasible to define concentration ranges that could serve as benchmarks for SA young wines, for all of the compounds analysed in this study. The concentration ranges for 8 compounds that were unaffected by the three vintage changes were reported, since this could be seen as an early indication of typical volatile composition of SA young wines.

The discriminant models for respectively white wine and red wine cultivars that were established showed very promising results. It would be of interest to re-validate the models with an independent set of wines to evaluate the robustness of these models, especially the "most used" models. It could also be of interest to determine the efficiency of the models for the classification of older single cultivar wines that have undergone more extensive maturation.

\section{LITERATURE CITED}

Arrhenius, S.P., McCloskey, L.P., Sylvan., M., 1996. Chemical markers for aroma of Vitis vinifera VAR. Chardonnay regional wines. J. Agric. Food. Chem. 44(4) $1085-1090$.

Aznar, M., Lopez, R., Cacho, J.F., Ferreira, V., 2001. Identification and quantification of impact odorants of aged red wines from Rioja. GC-Olfactometry, Quantitative GC-MS, and odor evaluation of HPLC fractions. J. Agric. Food. Chem. 49, 2924 - 2929.

Barbe, J.C., Pineau, B., Ferreira, A.C.S., 2008. Instrumental and sensory approaches for the characterization of compounds responsible for wine aroma. J. Chem. Biodiver. 5, 1170 - 1183.

Cabrita, M.J., Costa Freitas, A.M., Laureano, O., Borsa, D., Di Stefano, R., 2007. Aroma compounds in varietal wines from Alentego, Portugal. J. Food Comp. Anal. 20, 375 - 390 .

Calleja, A., Falqué, E., 2005. Volatile composition of Mencía wines. Food Chem. $90,357-363$.

Camara, J.S., Alves, M.A., Marques, J.C., 2006. Multivariate analysis for the classification and differentiation of Madeira wines according to main grape varieties. Talanta 68, 1512 - 1521.

Campo, E., Cacho, J., Ferreira, V., 2006. Multidimensional chromatographic approach applied to the identification of novel aroma compounds in wine: Identification of ethyl cyclohexanoate, ethyl 2-hydroxy-3-methylbutyrate and ethyl 2-hydroxy-4-methylpentanoate. J. Chromatogr. A 1137 (2), 223 - 230.

Conde, C., Silva, P., Fontes, N., Dias, A.C.P., Tavares, R.M., Sousa, M.J., Agasse, A., Delrot, S., Gerós, H., 2007. Biochemical Changes throughout Grape Berry Development and Fruit and Wine Quality. Food 1 - 22.

Danzer, K., De La Calle-Garcia, D., Thiel, G., Reichenbächer, M., 1999. Classification of wine samples according to origin and grape varieties on the basis of inorganic and organic trace analyses. Am. Lab. October, 26 - 34.

Etievant, P.X., 1991. Wine. In: Volatile Compounds in Food. Ed. H. Maarse. Food Science and Technology. (Marcel Dekker Inc.: New York) pp. 483 - 546,

Falqué, E., Fernández, E., Dubourdieu., D., 2001. Differentiation of white wines by their aromatic index. Talanta 54, $271-281$

Ferreira, V., Lopéz. R., Cacho, J.F., 2000. Quantitative determination of the odorants of young red wines from different grape varieties. J. Sci. Food Agric. $80,1659-1667$. 
Ferreira, V., Aznar M., Lopez, R., Cacho, J. 2001. Quantitative gas chromatographyolfactometry carried out at different dilutions of an extract. Key differences in the odor profiles of four high-quality Spanish aged red wines. J. Agric. Food Chem. $49,4818-4824$

Gil, M., Cabellos, J..M., Arroyo, T., Prodanov, M., 2006. Characterization of the volatile fraction of young wines from the Denomination of Origin "Vinos de Madrid" (Spain). Anal. Chim. Acta. 563,145 - 153.

Guth, H., 1997. Quantification and sensory studies of character impact odorants of different white wine varieties. J. Agric. Food. Chem. 45, 3027 - 3032.

Lacey, M.J., Allen, M.S., Harris, R.L.N., Brown, W.V., 1991. Methoxypyrazines in Sauvignon blanc grapes and wines. Am. J. Enol. Vitic. 42, 103 - 108.

Lambrechts, M.G., Pretorius, I.S., 2000. Yeast and its importance to wine aromaa review. S. Afr. J. Enol. Vitic. 21, 97 - 125.

Lee, S., Noble, A.C., 2003. Characterization of odor-active compounds in Californian Chardonnay wines using GC-olfactometry and GC-mass spectrometry. J. Agric. Food. Chem. 51, 8036 - 8044.

Lopéz. R., Ferreira, V., Hernández, P., Cacho, J.F., 1999. Identification of impact odorants of young red wines made with Merlot, Cabernet Sauvignon and Grenache grape varieties: a comparative study. J. Sci. Food Agric. 79, 1461 - 1467.

Louw, L. Chemical characterization of South African young wines. M.Sc. (Wine Biotechnology) thesis, Stellenbosch University, 2007. Private Bag X1, 7602 Matieland, South Africa. Retrieved from Stellenbosch University e-thesis database (www.sun.ac.za/library).

Louw, L. Roux, K., Tredoux, A., Tomic, O., Naes, T., Nieuwoudt, H.H., Van Rensburg, P., 2009. Characterization of selected South African young cultivar wines using FTMIR spectroscopy, gas chromatography and multivariate data analysis. J. Agric. Food Chem. 57(7) 2623-2632.

Marias, J., Van Rooyen, P.C., Du Plessis, C.S., 1981a. Differentiation between wines originating from different red wine cultivars and wine regions by the application of stepwise discriminant analysis to gas chromatographic data. S. Afr. J. Enol. Vitic. 2 (1), 19 - 23.

Marias, J., Van Rooyen, P.C., Du Plessis, C.S., 1981b. Classification of white cultivar wines by origin using volatile aroma compounds. S. Afr. J. Enol. Vitic. $2(2), 45-49$.
Noble, A.C., Flath, R.A., Forrey, R.R., 1980. Wine head space analyis. Reproducability and application to varietal classification. J. Agric. Food. Chem. $28,346-353$.

Otto, M., Pattern recognition and classification. In Chemometrics: Statistics and Computer Application in Analytical Chemistry. Wiley VCH: Weinheim, Germany, 1999.

Peinado, R.A., Moreno, J., Bueno, J.E., Moreno, J.A., Mauricio, J.C., 2004. Comparative study of aromatic compounds in two young white wines subjected to pre-fermentative cryomaceration. Food Chem. 84, 585 - 590.

Rapp, A., Mandery H., 1996. Wine aroma. Experientia 42, 873 - 884.

Schreier, P., 1979. Flavor composition of wines: a review. CRC Crit. Rev. Food Sci. 12,59 - 99 .

Sefton, M.A., Francis, I.L., Williams, P.J., 1993. The volatile composition of Chardonnay juices: a study by flavor precursor analysis. Am. J. Enol. Vitic. 44, $359-370$.

Skov, T., Ballabiob, D., Bro, R., 2008. Multiblock variance partitioning: A new approach for comparing variation in multiple data blocks. Anal. Chim. Acta 615, $18-29$

Tredoux, A., de Villiers, A., Majek, P., Lynen, F., Crouch, A., Sandra, P., 2008. Stir bar sorptive extraction combined with GC-MS analysis and chemometric methods for the classification of South African wines according to the volatile composition. J. Agric. Food Chem. 2008, 56 (12), 4286 - 4296.

Van Wyck C.J., Augustyn O.P.H., De Wet P., Joubert W.A., 1979. Isoamyl acetate, a key fermentation volatile of wines of Vitis vinifera cv. Pinotage. Am. J. Enol. Vitic. 30, 167 - 173

Viviani, A., Moreno, J., Peinado, R.A., 2007. Differentiation of young red wines obtained from a warm climate region. Int. J. Food Sci. Tech. 42, 523 - 527.

Weldegergis, B.T., Crouch, A.M., 2008. Analysis of volatiles in Pinotage wines by stir bar sorptive extraction and chemometric profiling. J. Agric. Food Chem. $56(21), 10225-10236$.

Zhang, M., Xu, Q., Duan, C., Qu, W., Wu, Y., 2007. Comparative study of aromatic compounds in young red wines from Cabernet Sauvignon, Cabernet Franc, and Cabernet Gernischet varieties in China. J. Food. Sci. 72:5, 248 - 252. 